Indeed, there is more evidence to show that rickets occurs from want of fat than from want of mineral salts. Rickety children are generally found to have had too little fat in their food, whilst, conversely, children fed on plenty of milk, bacon, \&c., remain free. Moreover, the administration of fat in the form of cod-liver oil is a most satisfactory kind of treatment. Fat, added to lean horseflesh, has prevented rickets in young carnivora, and oilcake given to ewes on a poor farm may stop the otherwise inevitable production of rickety lambs. Rickets is thus seen to be essentially dixe to an impairment of general nutrition, cold, damp, and deficient ventilation sharing also in the causation of the disease as instanced in - the case of puppies kept in damp cellars. But, further, it is important that the animal should be fed on its proper food, and therefore an a priori objection may be raised to many of the experiments made on animals. The very fact of giving an abnormal diet or of withdrawing some oustomary article may itself disturb the general nutrition and lead to rickets. Monkeys and other tropical animals kept under artificial conditions in this country show a tendency to rickets, a disease from which they do not suffer in their wild state. Indeed, anything which impairs general mutrition, such as the delicacy of constitution produced by interbreeding, especially in dogs, tends to originate rickets. Hence also it frequently complicates the wasting diseases of children, such as syphilis. The rarity of rickets among the poor in climates warmer than our own may be due not only to the cheapness and plenty of vegetable foods, such as maize, which contains fat, as well as the more general use of milk ismongst the poor, brt also that not so much of the fat is required for consumption in order to maintain the heat of the body. An impairment of general nutrition, rather than the absence of any special articles from the diet, serves therefore as the best explanation of rickets. The bone-forming cells being at the time particularly active are amongst the first to suffer. In order to form bone these cells have to extract firom the bloof the phosphate and lime they require just as do other secretory cells-e.g., those of the mammary gland The ash of dog's blood contains only 0.9 per cent. of lime and 13.3 per cent. of phosphates, and the ash of dog's serum 2.1 jer cent. of lime and 5.9 per cent. of phosphates. Ossification clearly demands some energetic action on the part of the cell in gathering out from the blood and secreting these salts which exist in such small quantities in it. A supply of phosphorus in some form must be constantly necessary for that element is an essential characteristic of nucleo-albumin, and it is upon its nucleus that the activity of a cell depends. The causes of the various forms of late rickets are similar in principle to those giving rise to the earlier variety, such as want of food, a lack of fat in the diet, cold, damp, bad air, and exhausting diseases. Girls suffer the most, perhaps ewing to menstruation and anæmia. One girl was dying from phthisis and another from exophthalmic goitre when the bones were attacked. Special cases in boys about puberty have been attributed to bad habits (Lucas). But there are two other phenomena met with in some cases of rickets which are not due to delayed ossification. There may be anapid absorption of bone or, on the other hand, an excessive bone formation.

Bone absorption in rickets.-Rapid absorption of bone in consequence of an increased supply of arterial blood happens in severe cases of rickets. There may be external signs of cnflammation- viz., redness, heat, pain, and excessive sweating-and this not only in the neighbourhood of the epiphyses, but also in such flat bones as the skull. The ends of the long bones become of a much more cancellous structure, whilst the skull may be rendered as thin as paper, or at least much more porous than normal. The older the patient the more striking is the fact. After a child has long learnt to walk it may be attacked by rickets, and bending may still occur. But as the cases become older and approach puberty multiple fractures happen instead or take place along with the curving.

Bone formation in rickets. - On the other hand, in the later stages of rickets or where the disease progresses but slowly an excessive formation of bone takes place. This may be seen as a great thickening of the skull and as osteosclerosis in the long bones. I have already brought forward the fact that excessive formation of bone is due to menous congestion, whether arising from chronic inflammation or not. This excessive formation of bone takes place both in men and animals. The shafts of the long bones undergo marked osteo-sclerosis-they become heavy and very hard. The skull may be thickened by porous bone (Briscoe), but even still more marked thickenings of the skull are seen in animals. In monkeys and lions dying in the Zoological Gardens Sutton has described such extreme thickenings of the skull as to cause death by pressure on the central nervous system. It will be noted that these tropical animals are liable in this country to both early and late rickets, although they remain free in their wild state. I have already noted a parallel instance in man-viz., the absence of rickets from India as compared with this country.

Serile clanges.-In all the changes of bone taking place in the decline of life we must recognise as one of the factors the gradual failure of general nutrition. It may be an important factor in some cases, in others only one among others. With diminished muscular use will come a diminished vascular supply, and so a smaller formation of bone in the parts of the bone pulled on by muscles. This may be combined with small disturbances of the regulating control of the nervous system without any nervous disease.

\section{ACTINOMYCOSIS INVOLVING THE SKIN, ANU ITS TREATMENT BY IODIDE OF POTASSIUM.}

[WITH GOLOURED ILLUSTRATION.]

BY MALCOLM MORRIS, F.R.C.S. EDIN., SURGEON TO THE SKIN DEPARTMENT, ST. MARY'S HOSPITAL.

ALTHovgh actinomycosis in the human subject is probably not so rare as till lately it has been supposed to be, it is still met with, or at any rate recognised, infrequently enough to make it worth while to report cases in which there has been an opportunity of studying its evolution and clinical manifestations and the effect of treatment. The following case which I have recently had under observation appears to me to be important as an illustration of the therapeutic action of iodide of potassium in this disease, more especially as the efficacy of this remedy in actinomycosis seems as yet to be imperfectly appreciated in this country. For the notes of the case I am indebted to my clinical assistant, Mr. J. W. Skevington.

A single woman aged fifty-nine years came under my care at St. Mary's Hospital on Nov. 18th, 1895, with a large swelling over the lower jaw on the left side. About Oct. 10th she first noticed a small nodule behind the ramus; it was just underneath the skin, and in about seven days began to discharge. It was very painful and continued to increase until she came to the hospital. The patient had for the greater part of her life been in service as a housemaid, but for about a year before the beginning of her illness she had made her living as a needlewoman. She stated that she had never lived over a stable, and had nothing to do with horses, cows, or other animals, nor with grain, hay, or straw. There was no history of a blow or other injury and she could throw no light on the origin of the disease. Her record of previous illnesses showed nothing that could be interpreted as having any bearing on her condition, nor was there anything of significance in her family history. She had a large dark red nodular tumour with a sharply circumscribed edge on the left side of the face. It extended from the angle of the lower jaw forwards to the corner of the mouth, upwards to the zygomatic arch, and downwards over the sterno-mastoid for about two inches. Here and there on the surface there were small scars, and the skin, especially at the lower part in the neck and about the corner of the mouth, was drawn into folds by cicatricial contraction, giving the swelling a puckered appearance about the edges. On the most prominent part, in the temporo-maxillary region, the surface of the mass was irregularly raised into nodules varying in size from a split pea to a small bean, each having a small opening at the top, the position of which was marked by a yellow bead of pus. On squeezing the nodules a little sero-purulent matter escaped. In this discharge were found firm yellowish-grey granules which microscopic examination showed to be masses of actinomyces or ray fungus. The skin over the whole mass was brawny and reddened. To the touch the swelling at first gave the impression of cartilaginous hardness, but on firm pressure between the fingers it was felt to be elastic. There was no 
fluctuation. Narrow spurs of infiltration also extended upwards behind the lobe of the ear and backwards to the posterior border of the sterno-mastoid. A hard lump of the size of a large hazel nut could be felt under the buccal mucous membrane. The structures forming the cheek were infiltrated and firmly fixed to the jaw, especially towards the angle, but the bone itself was not implicated. There were no teeth in either jaw except the left superior external incisor and canine. No cnlargement of glands, either concatenate or supra-clavicular, could be felt on the left side of the neck, and there was no evidence of secondary growths. There was no trismus, but the patient complained of great pain, particularly on mastication, and the nodules were tender on pressure. She had a poor appetite and slept baclly, but otherwise there was no disorder of the general health. How the infection was conveyed in this case there is no evidence to show, but of the nature of the disease there was no doubt. The microscopic examination was conclusive; apart from this, however, the situation and appearances of the swelling (see coloured plate) were characteristic. The internal administration of iodide of potassium was begun on Nov. 21st, when the following mixture was ordered to be taken three times a day: Potassii iodidi $15 \mathrm{gr}$, spiritus ammoniæ aromatici 20 minims, decoct. cinchonæ ad $\tilde{j}$. For the first three days after the commencement of treatment the pain was worse and the discharge was profuse, but after that the good effect was soon manifest. The pain abated, the swelling became paler and softer and began to shrink. After ten days of the treatment only slight traces of the fungus could be discovered in the discharge, which was very scanty. The patient was exhibited to the Dermatological Society of London on Dec. 11th, and at that time the growth had diminished to half its former size, and was much softer in consistence while the pain was very slight. On the 16th the dose of iodide of potassium was increased to $20 \mathrm{gr}$. and on Jan. 27th, 1896, to $30 \mathrm{gr}$. three times a day. The improvement continued, and, in short, the history of the case from the time the patient was brought under the influence of the iodide was a record of uninterrupted progress towards cure. Together with the retrocession of the local process appetite and sleep returned and the woman felt better than she had done for a considerable time. At the beginning of February the swelling had nearly disappeared, the sinuses had healed up, and only a trace of the disease was left. When last seen (May 28th) the patient was well, but was still taking the iodide.

There can be no doubt that actinomycosis has often been mistaken for gumma or other manifestation of syphilis, and the erroneous diagnosis must have appeared to receive confirmation from the beneficial effects of iodide of potassium. In other cases the disease has been looked upon as tuberculous or has been taken to be a malignant growthgenerally sarcoma, to which, indeed, it sometimes bears a close resemblance. It is generally easy enough to recognise actinomycosis when one is alive to the possibility of meeting with it in a given case; but the appearances are certainly very puzzling when such a contingency does not happen to be present to the mind. As actinomycosis, even when liberal allowance is made for errors in diagnosis, is not a common disease, and as there must be many members of the profession in this country who have never seen a case, it may not be amiss to give a short account of it in its ordinary manifestations. I have no pretension to be able to add anything to what is already known about the disease, but $I$ have lately had occasion to look through the recent literature bearing on the subject, and as even the most modern English text-books and special treatises give only a few lines to the description of the disease so far as it attacks the skin, I may, perhaps, be excused for trying in some measure to fill the gap at least provisionally.

Actinomycosis is a parasitic disease, the lesions being the result of a reactive process caused by the presence in the tissues of a living irritant, the actinomyces or ray fungus. This was first described as it occurs in the so-called osteo-sarcoma of animals by Rivolta in 1868 and more fully and more accurately by Harz and Bollinger ${ }^{1}$ in 1877. It was Harz who gave the disease caused by the parasite the name of "actinomycosis." In man it was first definitely recognised by J. Israel. ${ }^{2}$ The parasite had been seen and drawn by von Langen-

1 Centralb]att fuir die Medicinischen Wissenschaften, No. 27, 1877. Virchow's Archiv, Band lxxiv, 1878. beck $^{3}$ in 1845, but its nature was not understood by 1853 by Robin and Laboulbène ${ }^{4}$ which appear to hare been instances of actinomycosis, and foux years later the characteristic granules were noticed in pus from an abscess of the chest wall by Lebert, ${ }^{5}$ who, however, was unable to give an opinion as to their nature. The parasite had also been drawn independently by $\mathrm{Mr}$. T. Smith ${ }^{\circ}$ when examining the tissues of an obscure case for Sir James Paget about 1855. In 1879 Ponfick proved that the disease as it occurs in man is pathologically identical with that met with in animals.

Actinomycosis may attack almost any part of the body; but there are three principal points of invasion, the neck, the chest, and the abdomen. The cervico-facial region is the most frequent site of the disease; it has bees estimated that some 55 per cent. of all cases have this localisation, but the proportion is probably higher than this : thus of thirty-eight cases published in France top to the latter part of 1895 the disease was in this region in thirty. five. The lung and abdominal viscera come next. The limbs suffer comparatively seldom. Cases are, however, recorded in which the disease attacked the hand by Bertha ${ }^{7}$ and Müller and the lower limbs by Marten, ${ }^{9}$ and Pringle. ${ }^{10}$ Crookshank and Kanthack ${ }^{11}$ maintain that one variety of the affection of the foot familiar to Indian practitioners under the name of "madura foot" or mycetoma is in reality a form of actinomycosis caused by a variety of the ray fungus, but this theory must be considered as yet " not proven." The points of difference between the fungus of actinomycosis and that of mycetoma have been fully described by Surveyor and Boyce. ${ }^{12}$ The skin is extremely selclom primarily attacked by actinomycosis, but it is very often secondarily invaded by extension of the process from the underlying tissues.

In this paper I am chiefly concerned with actinomycosis as it affects the skin, and in the following description I will take the temporo-maxillary form of the affection as the type. The most common situation of the disease is the space roughly limited behind by the ramus of the jaw, below by the body of that bone, and above by a line from the temporo. maxillary joint along the zygoma. This localisation is doubt. less due to the fact that the fungus as a rule finds its way into the tissues through the mouth, the point of entrance being a carious tooth or an erosion of the mucous membrane. Bertha reports two cases of direct inoculation of the skin of the hand by means of grain. Sometimes it gains access through. a breach of the skin surface caused by injury; what appears to be an instance of this mode of invasion has lately been reported by Guillemot. ${ }^{14}$ A man was struck on the face by a piece of wood and a few weeks later an actinomycotic swelling developed on the exact site of the blow. Müller ${ }^{\bar{s}}$ has recorded a case in which a woman ran a splinter of wood into ber finger and two years later a* swelling formed in the same situation which was proved by microscopic examination to be of actinomycotic nature; the chip of wood was found imbedded in the diseased tissues. Although there are no precise data by which to estimate the period of latency I find it difficult to believe that it can beas long as two years; it appears more probable that inocula tion took place through the wound. In animals the fungus is mostly conveyed into the body by the food, and ir man the fungus is no doubt sometimes introduced by tin pieces of grass, hay, corn, \&o., which are chewed or unwittingly swallowed. The most common habitat of the fungus is the surface of certain vegetable substances, especially grass and cereals, particularly in the dry state. A piece of straw may be at once the means of conveying the fungus into the mouth and the instrument of inoculating it in the tissues by making a tiny scratch on the mucous membrane. Thus Poncet ${ }^{16}$ reports a case in a woman who was accustomed to carry in her mouth wisps of straw for

4 Besse: De l'Actinomycose Cervico-faciale, Lyons, 1895, p. 69

A. A. Kanthack : St. Bartholomew's Hospital Journal, January, $1895^{\circ}$ Wiener Medicinische Wochenschrift, 1888, No. 35.

8 Bruns : Beiträge zur Klinischen Chirurgie, Band iii,, Heft 3, p. 355.

10 Transactions of the Royal Medical and Chirurgical Societ $y_{\text {. }}$ ol. Ixxviii., 1895

II Journal of Patbology and Bacteriology, vol. i., 1892. Vandyke Carter suggested in 1886 that some forms of mycetoma are produced by a fungus akin to actinomyces.

12 Proceedings of the Royal Society of London, 1893.

13 Loc. cit. 16 Gacette Hebdomadaire, April, 1895
16 
Supplement to The LANCET.

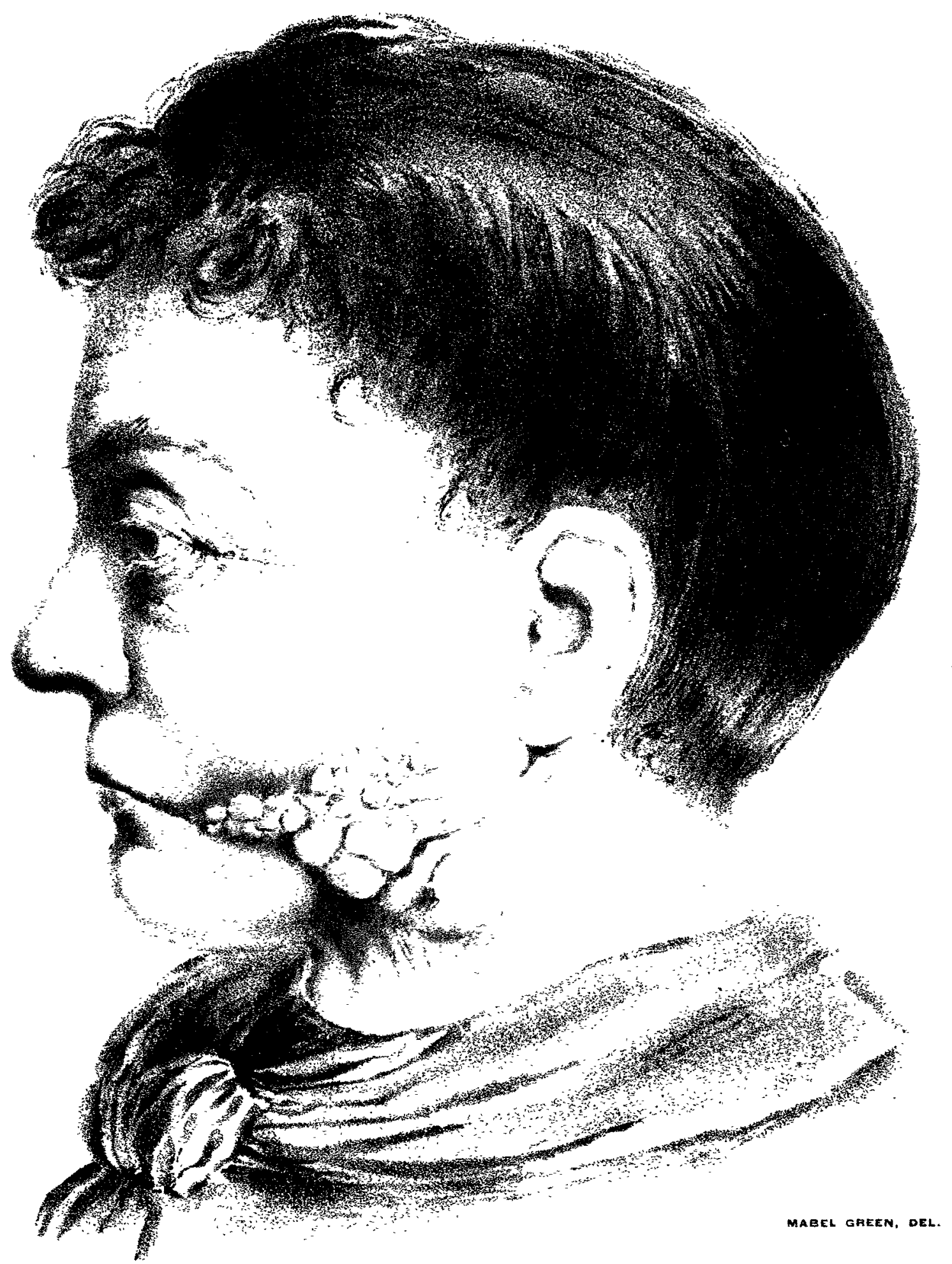



tying up vines; and another ${ }^{17}$ in a man who had a habit of chewing bits of grass and straw; Dubreuilh and Frèche ${ }^{13}$ ceport a case in a man who used to pick his teeth with straw, with which he sometimes made his gums bleed; Monestié ${ }^{19}$ relates one in a girl who was in the habit of chewing straw ; and Besse ${ }^{30}$ one in a man who was accustomed to chew grain. Guermonprez and Augier ${ }^{21}$ have recorded a case in which a man wounded his gum with a piece of cornstalk; eight days later a hard, painless swelling, which proved to be of actinomycotic nature, appeared in the exact situation of the scratch. There is some evidence that the actinomyces may be introduced in to the system in meat from animals that have suffered from the disease, in vegetable substances such as cereals, potatoes, \&c., and even in milk. ${ }^{22}$ The - disease may also be transmitted directly from animals to human beings or from the latter to each other. Baracz ${ }^{23}$ thas placed on record a case in which it was communicated by a man to a woman by kissing, and cases in which it has zoen transmitted from animals to human beings have been ceported by Poncet, Mayde, Bulhoes-Hartman, and others. ${ }^{24}$

As regards the etiology there is little more to be said; neither age nor sex can be regarded as a factor except in as tiar as they have any connexion with occupations exposing to the risk of infection. 'That the soil has an influence, tfavourable or unfavourable, on the growth of the parasite in the tissues is obvious, not only from the very different degrees of severity of the disease, but from the very marked differences of type in which we meet with it clinically. Of the causes of these differences, however, we know nothing. The published literature might suggest that the disease is far more frequent in some parts of Germany and particularly in Austria than elsewhere, but this is probably in large measure due to its being more carefully looked for in those countries. It is significant that whereas France used to be thought to be exempt from actinomycosis, no fewer than twenty-four cases have been recorded in that country since 1894 ; it is still more significant that of that number twelve have occurred in Lyons, nine of them in the practice of one surgeon, M. Poncet. ${ }^{25}$ It appears a fair inference, therefore, that actinomycosis will be recognised more frequently the more carefully it is looked for. In many cases, as in the one reported above, the mode of infection cannot be precisely determined. According to M. Arloing, ${ }^{26}$ the spores are scattered about in nature in considerable abundance, being generally present in greater or less mumbers on organic substances in course of becoming mouldy. These spores may penetrate by inoculation into the tissues and they may also gain entrance through the respiratory passages, spreading thence into various parts of the organism by the ploodvessels. As the mycelial tubes have no distinct sheath such as is found in ordinary moulds, they are easily broken ap and may be scattered about to great distances. I give these facts on the authority of M. Arloing, a man not given to uttering base scientific coin; the wonder, therefore, is not that actinomycosis should of ten develop without traceable cause, but that it is not a much more common disease than it is.

The fungus having found its way into the economy after a period of incubation not less than four weeks sets up an inflammatory process, the exact course and results of which are dependent on the nature of the tissues in which it us embedded. The essence of the process is that a derelopment of granulation tissue takes place round the fungus; a nodule is thus formed, the interior of which soon breaks down into a thin liquid containing tiny granular bodies. Byand-bye the neighbouring nodules coalesce into a tumourlike mass, hard and solid at first, but before long suppurating in different places and giving rise to small abscesses, which may run together and form cavities of considerable size. The skin covering the swelling is at first red and brawny; as tension increases it becomes livid and soft and finally gives way, generally in several places. Through the openings there escapes a thin serous or sero-

17 Mercredi Médical, June 19th, 1895.

18 Annales de Dermatologie, September, 1895.

20 De l'Actinomycose Cervico-faciale, Lyons, 1895, p. 67.$$
23 \text { Quoted by Resse: loc. cit., p. } 37 .
$$$$
24 \text { Ibid. }
$$

25 Besse : loc. cit., p. 71. According to a more recent communication by Poncet (Bulletin de l'Académie de Médecine, April 14th, 1896), the number of cases recorded in $\mathrm{Frence}$ up to that date was between forty and fifty. Of these, twenty were observed in L Lons.

20 Lyon Médical, Dee. 22nत, 1895, p. 571. purulent discharge, containing jellowish grey or whitish granules, which to the finger feel firm and res'stant; these are masses of spores of the ray fungus. The openings of the sinuses closely resemble those leading to diseased. bone, but on probing no bare bone is struck. The sinuses have soft, fungating walls and are often partly filled with broken-down tissue; they communicate with cavities lined with similar material in which the characteristic yellowish granules are present in greater or less abundance. For a considerable time the process is confined to the soft tissues, especially to the subcutaneous cellular tissue, muscles, \&c. 'The periosteum may also be thickened, but the bones are very seldom attacked, and then only secondarily. In some rare cases, however, the process invades the bones almost from the first; thus Poncet ${ }^{27}$ has recorded a case in which the bones of the upper jaw and the corresponding half of the bard palate were completely destroyed in five months, the soft parts of the cheek remaining unaffected. It is a curious fact, of which I have seen no explanation, that in animals the bone is always invaded, and, in fact, is generally the starting-point of the process, whereas in man the general exemption of the bone is one of the characteristic features of the disease. On the other band, suppuration, which is the rule in the human subject, never occurs in animals. The suppuration caused by the actinomyces itself in man is of a peculiar character, the pus formation being extremely scanty and the pus itself generally thin, though very sticky. As the process continues, however, pus-cocci gain access and set up active suppuration, the ravages of which extend wide and deep, destroying the temporal, masseter, and pterygoid muscles and not sparing the bone. In this stage the characteristic features of the disease are lost in a mass of inflamed and disintegrating tissues, fungating here and there through the skin, which is riddled with sinuses and fistule intercommunicating with each other in an inextricable labyrinth.

The appearances of actinomycosis as it affects the skin in ther parts of the body have been well described by Pringle 28 in the case of a boy under his care in the Micldlesex Hospital in whom the primary seat of disease appears to have been the respiratory tract. The skin lesions were situated on the back. "The most striking feature of the eruption is constituted by enormous livid, fleshy, sarcomatous-looking outgrowths of mottled purplish and yellow colour. ..... All the growths feel pulpy and fluctuating and are not tender; each growth presents at least one, usually several, small crateriform ulcerative openings, from which a clear, rather sticky fluid constantly exudes. ...... In each of these ulcerative surfaces there is an accumulation of purulent fluid of pale sulphur-yellow colour, which is seen to contain innumerable tiny granular specks." Over the part of the chest there were deep brown pigmented sunken cicatrices, the marks of lesions similar to those on the back, which have discharged their contents. Over the great trochanter are three similar pigmented scars, which still show some signs of activity.

Actinomycosis may run an acute course, but as a rule the process is chronic, sometimes with occasional exacerbations. The typical form, that which affects the parts about the angle of the jaw and the temporal region, often begins with pains about the back molar teeth, which may be decayed, or in the temporo-maxillary joint itself, where the pain is sometimes so intense as to suggest arthritis. Another symptom which not infrequently precedes the appearance of swelling is trismus, the closure of the mouth apparently being due to reflex spasm of the masseter and temporal muscles caused by the irritation of the parasite. The trismus is often so severe as to make feeding a matter of great difficulty. The swelling usually first shows itself at the angle of the jaw and spreads upwards along the ramus, infiltrating the temporal region and the cheek and sometimes the part behind the ear. From the slight degree of redness of the skin covering it and from its indefinite outline and nodular surface the swelling is in its appearance at first more sugrestive of a new growth than of an abscess. To the finger it feels solid like cartilage or even wood, but yet elastic. As Poncet says, an actinomycotic swelling gives to the touch a sense of something unfamiliar. its consistence being between that of a hard tumour and of inflammatory cdema: the impression given to the finger is, as he expresses it, as if the connective tissue in the affected region had been infiltrated with some coagulating substance. Diffused through the mass of the swellirg nodules of varying 
size can be felt. On passing the finger into the mouth the swelling can be felt projecting into the cavity; the mucous membrane is sound and the mass can be felt lying outside it, smooth and dense as on the face. Pointing as a rule takes place towards the exterior, not towards the mouth. Waring ${ }^{29}$ has, however, recorded a case in which the swelling burst into the buccal cavity. After a variable time sligbt fluctuation may be perceptible at one or more places, and the skin in those spots becomes livid and thin and finally breaks, giving issue to a little fluid in which are seen the granular masses containing the parasites. Squeezing causes the escape of more yellowish bodies, but not, as a rule, of any amount of pus. Long sinuses are formed from which matter containing the yellowish grarules of the fungus is discharged from time to time. When the contents have been completely got rid of the opening heals up, and when there are several such small "extinct volcanoes," if I may call them so, the contraction gives rise to the puckering in the swelling which is one of the most characteristic appearances of the disease. There is seldom any enlargement of neighbouring glands, the fungus being too large to make its way along the lymphatics. When, however, suppuration runs riot and the original disease has become complicated by the invasion of pyogenic microbes the glands may be involved in the general conflagration. Secondary foci of the disease may develop in neighbouring parts, as the neck, the cheek, the temple, \&c., the fungus burrowing its way along in the loose connective tissue, under fasciæ and in the sheaths of blood-vessels and muscles. The evolution of these secondary swellings is similar to that of the original mass.

In the ordinary chronic form actinomycosis in the earliest stages, when the lesions are purely local, is not accompanied by any particular derangement of the health, though much suffering may be caused by pain and the patient is weakened by want of sleep and inability to take food; if the process continues his strength is further drained by prolonged suppuration; and if the larynx, cesophagus, lungs, nervous system, \&c., be attacked corresponding symptoms will be produced. The disease if left to itself tends to spread both by continuous extension and by metastasis. It may extend downwards in the subcutaneous tissue in the front of the neck or at the side along the sterno-mastoid, reaching the supra-clavicular region or passing into the axilla, and fixing the whole neck from the chin to the sternum in a rigid casing $;^{80}$ or passing below the superficial cervical fascia it nay spread downwards into the anterior mediastinum, perhaps ulcerating into the air passages on its way, and finally attacking the lungs and the heart; sometimes it extends upwards to the base of the skull, attacking the meninges and the brain, or it invades the spinal cord. In any of these lines of extension the mass may erode the walls of bloodvessels with consequent formation of fresh foci in the viscera. Death may occur from exhaustion, amyloid degeneration of the liver, \&c., or septicæmia. In certain rare cases actinomycosis runs an acute course, beginning suddenly with high fever and great swelling of the neck, sometimes spreading to the floor of the mouth, the tongue, and the pharynx; the affection in such cases strikingly resembles angina Ludovici and death may occur in less than a week from the onset.

Fortunately, actinomycosis is fairly amenable to treatment if taken in time, and if properly dealt with the formidable complications that have been alluded to can often be prevented. It must be borne in mind, however, that actinomycosis, particularly in the temporo-maxillary form, is of two very distinct types-one comparatively mild, in which the affection is easily controlled or may come to a standstill or undergo spontaneous cure, and another in which it has in it an element of malignancy which simply defies treatment. There can seldom nowadays be any difficulty about the diagnosis, except in the initial stage, before the skin has given way and allowed the characteristic granular bodies to escape. The yellowish-grey bodies can readily be identified with the naked eye when once they have been seen, but reliance must not be placed on such perfunctory inspection; masses of cholesterin crystals have been taken for actinomyces, and a microscopic examination should be macle in all cases. Even with the aid of the microscope the characteristic bodies are not always easy to discover. Microscopically the granular bodies consist of rounded masses of leptothrix filaments surrounded by a fringe of club-shaped bodies radiating from the centre. The morphology and life- history of the parasite will be found fully described in the writings of Ponfick, ${ }^{31}$ Israel, ${ }^{32}$ Crookshank, ${ }^{33}$ and Kanthack, ${ }^{33}$ to which I refer the reader. Poncet, who has given great attention to the subject, holds that the diagnosis can generally be made from the symptoms alone. The signs on which he lays stress are: (1) the character of the pain, which is not continuous, is mostly worse at night than in the day, is not tensive like that of an abscess, and is often noi relieved by incision: (2) the early occurrence of trismus not dependent either on pain-since it is present in cases where there is little or no pain-or on swelling; this symptom according to Poncet is pathognomonic; (3) the situation and peculiar wooden teeling of the swelling; and (4) the respect for the bony structures generally showr by the process. The absence of glandular enlargement is another distinctive feature. Actinomycosis might possibly at the very outset be mistaken for periostitis due to dental caries ; in the latter condition, however; the bone is pretty sure to be attacked, in any case the decayed teeth would have to be extracted and the progress of events would speedily clear up the diagnosis. The prognosis may be gathered from what has been said in describing the course of the disease and the different types which it may assume. In general terms it may be stated that the acuter the onset the graver is the outlook; and, on the other hand, the slower the course and the more localised the process the more likely is the discase to yield to treatment. Besse's figures show that in the ordinary cervicop facial form the average mortality is about 8 per cent., but when the upper jaw is the seat of disease the fatality is much greater. Of 16 cases of this description under Poncet 8 died. Jirou gives the following death-rates for the different forms of actinomycosis: of face and neck, 11 per cent. thoraco-pulmonary, 83 per cent.; abdominal, 31 per cent.; and cerebral, 100 per cent.

Actinomycosis can often, as in the case which forms the basis of this communication, be cured by the internal administration of iodide of potassium alone. It is remarkable that the use of this drug, which is now known to be almost as certain a specific in actinomycosis as it is in tertiary syphilis, should still be unfamiliar to Englisb practitioners. It is not mentioned at all in some recents works on diseases of the skin, including $\mathrm{my}$ own, and it is referred to only in the most cursory manner in text-books of surgery published within the last twelve months. It was; first used in veterinary medicine by Nocard ${ }^{35}$ in 1885, and also by Thomassen ${ }^{36}$ of Utrecht. In Chicago, out of $185 \mathrm{oxem}$ suffering from the disease, 71 were cured by iodide of potassium. ${ }^{37}$ In the human subject it seems to have been first used by Netter. ${ }^{38}$ It was soon afterwards successfully employed by Buzzi and Galli-Vallerio. ${ }^{39}$ In Holland instances of cure by means of this remedy have been recorded by Van Itelson of Leyden, Salzer of Utrecht, and others. In France it has been successful in the hands of Meunier, ${ }^{40}$ Gaube, ${ }^{41}$ Jaboulay, ${ }^{42}$ Dubreuilh and Frèche ${ }^{43}$ Legrain, ${ }^{4-4}$ Monestié, ${ }^{45}$ and Duguet: ${ }^{46}$ and Poncet and his pupils Jirou and Besse bear emphatic testimony to its value. Rydygier ${ }^{47}$ of Warsaw also speaks favourably of its use ; in Denmark it has been used successfully by Schon; ${ }^{48}$ and in America it has been tried with excellent results by Van Arsdale. ${ }^{49}$ Milton ${ }^{50}$ cured a case in the Kasr el-Aini Hospital in Egypt, the first recorded in that country, with large doses of iodide. In this country Pringle ${ }^{51}$ has obtained very encouraging results in one case with the

31 Actinomycose des Menschen. Berlin, 1882.

32 Actinomycose des Menschen. Berlin, 1885. See Microparasites in

Disease. New Sydenham Society, 1886, p. 463 et. seq.

33 Transactions of the Royal Medical and Chirurgical Society, 1892.

35 In a communication to the Société Centrale de Médecins

Vétérinaire. Quoted by Pringle, loc. cit.

36 Journal of Comparative Pathology, 1892.

37 Pringle, loc. cit.

9

40 Bulletin

41 Union Médicale du Nord-Est, March, 1894.

4 4asse: Loc. cit., p. 67.

(8) 45 Loc. cit.

46 Bulletin de l'Académie de Médecine, Dec. 31st, 1895.

47 Wiener Klinische Wochenschrift, November, 1895

${ }_{49}^{48}$ Ugeskrift for Læger, 1895, No. 50.

Annals of Surgery, September, 1895

51 Transactions of the Royal Medical and Chirurgical Society, 
iodide, although he did not give it in full doses. Iodide of potassium has also been used with success by Ward of Leeds. $^{52}$ I have heard privately of a few other cases in which the treatment has been successful in some London bospitals, but they are still unpublished.

The mode of action of the drug in actinomycosis is not yet clearly understood. It does not seem to kill or eren injure the parasite. Nocard found that a solution of 1 per cent. of iodide of potassium did not cbeck the growth of cultures in an artificial nutrient medium. Netter believes that the remedy has a specific action on the anatomical elements, increasing their power of resistance and thus strengthening the organism in its struggle against the disease. However this may be there can be no duubt of its influence for good. It causes a rapid subsidence of the tnmours and nodosities, the parasites are discharged through the sinuses or are absorbed, and ulcerated surfaces heal. In the case above recorded the therapeutic effect was even more striking than that of the drug in tertiary syphilis. The earlier the administration of the iodide is begun the surer and speedier is its action. In order to get the full effect it must be given in full doses. Beginning with ten or fifteen grains three times a day, it should be steadily pushed to twenty, thirty, forty grains, and even larger doses if necessary. The more active the disease the more energetic must be the medication. As a rule the drug is well borne, but if it comes to be what may be called a siruggle for life between the remedy and the disease any inconvenience liktly to be caused by the former is preferable to the almost certainly fatal effect of the latter. Poncet usually combines local applications of iodide of potassium with its internal administration. He injects a 1 in 100 solution into the sinuses and fistulæe or inserts pencils of the iodide resembling those often used for the application of iodoform. Others, as Rydygier, combine interstitial injections of a 1 in 100 solution into the mass with internal medication by iodide of potassium. The average duration of treatment by the internal administration of iodide of potassium is from six weeks to two months. Although the drug may almost be considered a specitic it must not be accounted infallible. Poncet records three cases ander his own care in which the disease went steadily on to a fatal issue, apparently uncontrolled by the remedy. Br. D. N. Knox ${ }^{j 3}$ has quite recently reported a case in which the drug was equally useless. On the other hand, in estimating the therapeutic efficacy of the iodide it must be borne in mind that there are cases of benign type which have a natural tendency to end in cure. Arsenic has been used alone or combined with iodide of potassium in cases of abdominal actinomycosis (perityphlitis actinomycotica) by Ammendorp ${ }^{5 t}$ and Tscherniug, ${ }^{55}$ both of Copenhagen. In a case under Darier's care, in which the affection was limited to the soft parts of the face, a cure was effected by electro-chem icıl treatment applied by Gautier; ${ }^{56}$ a solution of iodicle of potassium was injected into the diseased tissues, and a current was then passed through so as to decompose the substance and thus utilise the antiseptic power of iodine in its vascent state. Tuberculin was used successfully in one case by Billroth, ${ }^{57}$ and Ziegler ${ }^{58}$ has had good results with the same remedy. Thyroid extract has been employed by Pringle in two cases; one ${ }^{59}$ improved remarkably under the treatment; in the other ${ }^{60}$ the remedy did good at first, but had to be discontinued on account of the untoward symptoms caused by it. In many cases the internal medication mist be supplemented by surgical measure: Suppurative fosi must be lind open and drained; the walls of chronc sinuses and cavities must be curetted and purlited and necrosed bone mast be removed vlcers and wounds mint bs dealt with on ordinary antiseptic principles. It is hardlv within my province, however, to go Ento details on this subject.

A word or two respecting prophylaxis may not he out of place. Arloing recommends that all anmals suffering from actinomyces is in however mild a furm should be slaugbtered. If this measure is con-idered too drantic at least the meat frum such animals should be carefully inspected, and$$
\text { 51 The LaxceT, Jdn. 26th, } 1895 .
$$$$
3 \text { Glasgow Medical Journal, May, } 197
$$$$
\text { nt Hospitals: 'l'rdende, Band i., p. } 518 .
$$$$
56 \text { Annales do } 1 \text { bid., p. } 580
$$$$
56 \text { Annales de Dermatologie, 1891, p. } 449 .
$$$$
57 \text { Wiener Medicinische Presse, 1r91, p. } 350 .
$$$$
\begin{aligned}
& \text { s8 Minchener Medicinische Wouhe' schrift, } 1892 \\
& : 9 \text { British Journal of Dermatology, January, } 1896 .
\end{aligned}
$$

60 Transactions of the Royal Mediedl and Chirurgical Society จơ. lxxviii,, 18:5.
}

the same precautions should be adopted in the cooking of it as are enjoined by Dr. Woodhead ${ }^{61}$ relative to tuberculous meat. Milk from animals with "lumpy jaw" or "wooden tongue" should be boiled before use. A word of caution may be added as to the danger of chewing bits of grass or straw, as many people besides ostlers and Lord Palmerston (see Leech's carlcatures of that statesman passim) are in the habit of doing. As for picking the teeth or clearing out carious cavities with straw - a procedure I have known to be adopted-it can only be described as flying in the tace of Providence.

The following is a list of some of the most recent contributions to the literature of actinomycusis; the more important of the earlier works on the subject are referred to in the text.- Poncet: Notes
sur un Nouveau Cas d'Actinomycose Temporo-Haxillair e ; Considerasur un Nouveau Las d'Actinomycose Temporo-Maxillaix e ; Considera-
tions Cliniques Lyon Médical, Dec. 15th, 1895; De l'Actinomycose trons Cliniques Lyon Médical, Dec. 15th, 1895; De l'Actinomycose
Humaine à Lyon, Gazette Hebdomadaire, April, 1895; Sur un Nouveau Cas d'Actinomycose de la Face, Mercreai Médical, June, 1895 ; Actinomycose de la Région Cervico-Faciale, ibid., July, 1895; Bulletin de l'Académie de Médecine, April 14th, 1896. Jirou: Contribution à l'Etude de l'Actinomycose en France, Thèse de Lyon, 1894. Besse: De l'Actıomycose Cervico-Faciale; Nouvelles Observations
d'Actinom ycose en France, Thèse de Lyon, 1895. H. Langstein : Die d'Actinom ycose en France, Thèse de Lyon, 1895. H. Langstein : Die
Aktinomykose des Menschen, Prager Medicinische Wochensehrift, 1895, Aktinomykose des Mensehen, Prager Medicinische Wochensehrift, 1895,
Band xx., pp. 35, 50. Von Mosetig-Moorhot: Ein Fall von PseudoBand xx., pp. 35, 50. Von Mosetig- Mocrhot: Ein Fall von PseudoAktinomykuse seltener Ausbreitung, Wiener Medicinische Presse,
1895, Band xxx., Heft vi., pp. 1-7. IHE LANCET: Editorial Article on Actinomycosis, July 9th, 1892. Baumgarten: Letrbuch der Path. Mykologie. Majoccui : Bollettino delle Scienze Mediche di Bologna, 1892. J.J. Pringle: A Case of Actinomycosis extensively involving the Skin. Transactions of the Royal Medical and Chirurgical society, vol. Ixxviii., 1895. F. Monestié: Symptomatologie de l'Actinomycose Cutanée, Journal des Sciences Médicales de Lille, No. 39, 1895, and De l'Actinomycose Cutanée, Thèse de Paris, 1895. Bérard: Traitement de l'Artinomycose par l'Iodure de Potasse, Thèse de Bordeaux, 1897. Choux: Ettude Cinique et Thérapeutique de l'Actinomycose, Arcaives Générales de Médecine, April, lviay, June, 1890 (this is part of a very complete monograph on the subject for which the writer was awarded the Alvarenza prize by the Académie de Médecine in 1894). Dubreuilh et Frèche: Sept Cas d'Actinomycose dans le Sud-Ouest. Annales de Dermatologte et de Syphiligraphie, September, 1895. Quenet: De l'detinomycose du Liaxillarre Supérieur. Thèse de Lyon, 1895 . Summaries of what is known about actinomycosis are given by L. Bérard copious bibliography), and by Nacciarone in the Rito:ma Medica, March 23rd, 1896.

Harley-street, w

\section{THE SYMPTOMS AND TREATMENT OF DISEASES UF THE ATTIC (UPPER PAR'T OF 'THE MIDDLE EAK).}

BY ADOLPH BRONNER, M.D.,

SURGEON TO THE BRADFORD EYE AND EAR HOSPITAL ; LARYNGOLOGIST TO BRADFORD INFIRMARY,

BEFone discussing this important subject it would, perhaps, not be out of place to explain and describe a few of the terms used. The attic-also called recessus epitympanicus, or aditus ad antrum, or Kuppelraum-is the upper part of the middle ear and contains the head of the malleus and the greater part of the incus. The tegmen tympani forms the roof and Shrapnell's membrane and a ridge of bone above it form the outer wall. It is dividea into several cavities by the ligaments of the malleus and the incus and by folds of mucous membrane, which connect the ossicles with the walls of the attic. 'l'bese vary to a considerable extent. Shrapnell's membrane is the upper part of the imembrana tympanl. It is tbinner than the lower part or pars tensa, as it consists only of two layers (integumentary and mucous) and lacks the middle or fibrous layer. The attic plays a very important fart in connexion with the diseases of the middle ear and mastoid antrum, partly because of its position, as it is practically the connecting link between these two cavities, and partly because of its contents and the arrangement of the same. Inflammation of the middle ear can very readily spread into the attic, and when 1t has once got iuto the rarious cavities it rarely heals spoutaneously. This explains why the ossicles and walls of the attic are so frequently diseased. Often there is an accumulation of thickened exudation or pus, or we may find a genume cholesteatoma. Wall found caseous matter in the attic in forty-four out of sixty-five cases of perforation of Shrapnell's nembrane. My own experience quite agrees with these figures. It is difficult to localise the exact seat of the disease. 'l'he position of the perforation, however, helps us

61 See Report of Royal Commission on Tubereulosis. 